\title{
Food Waste Management (Sector) in a Circular Economy
}

\author{
Nicole Unger and Francesco Razza
}

\begin{abstract}
The presentations addressed the topic of food waste management in a circular economy from various angles. Understanding the amount of food waste generated and setting measures to prevent it should be the starting point. Any not prevented food waste should be valorised aiming at a positive triple bottom line (social, economic and environmental). The huge environmental and economic potential of co-digestion of dairy manure and food wastes by linking waste producers with costumers for derived products was demonstrated for the US. Further the link between bio-waste, compost and soil quality is highlighted which contributes to food security and the wider bio-economy. Looking forward research into the application of selected agri-food wastes to produce alternative sources of protein could result in more sustainable source of proteins able to compete with industrial chicken production. Overall, the presentations and discussions showed the multi-facetted nature of food waste management emphasising that a range of measures by many stakeholders are required to move towards a circular economy society.
\end{abstract}

\section{Introduction}

The Sustainable Development Goal 12.3, focuses on the food waste sector and sets the target to halve the per capita global food waste at the retail and consumer level by 2030 and to reduce food losses along production and supply chains, including post-harvest losses. The European circular economy package [1] explicitly aligns to this target and made food waste one of its priority areas. In the same document, the

\footnotetext{
N. Unger $(\bowtie)$

University of Natural Resources and Life Sciences,

Institute of Waste Management, Vienna, Muthgasse 107,

1190 Vienna, Austria

e-mail: nicole.unger@boku.ac.at

F. Razza

Novamont-Ecology of Product and Environmental Communication,

Piazz.le Donegani 4, 05100 Terni, Italy

(C) The Author(s) 2018

E. Benetto et al. (eds.), Designing Sustainable Technologies,

Products and Policies, https://doi.org/10.1007/978-3-319-66981-6_15
} 
EU focuses on boosting the market for secondary raw materials, which currently only account for a small proportion of materials used in the EU. With these ambitious targets, the need for science based guidance is eminent. Any approach tackling food waste needs to align to sustainable development, making environmental, social and economic sense. The aim of this session is to explore the role of waste management (sector) as industry and society move towards a circular economy model.

Four oral presentations by speakers from four countries addressed the session topic from different angles. Two presentations, by Sergiy Smetana and Francesco Razza have full papers accompanying them that are also part of this book.

\section{Food Waste Generation in Europe}

The management of food waste starts with understanding how much food waste is currently produced and what share of it can be prevented. Silvia Scherhaufer presented in this context outcomes of the EU FP7 funded project FUSIONS (http:// www.eu-fusions.org/) where this was evaluated on a European level.

Food waste and other side flows from the food supply chain include food and other, non-edible parts occur at every step of the supply chain. In total 88 Mio tonnes of food waste is generated in Europe per year, the majority (about 53\%) occurring during food preparation and consumption at home. Based on these figures, 31 Mio tonnes of food wastes would need to be reduced each year in order to meet the United Nations' Sustainable Development goal by 2030.

Silvia Scherhaufer then further expanded the procedure developed to estimate the impacts of the food supply chain and impacts which can be related to food waste including food waste management [2]. For example, in order to provide $1 \mathrm{~kg}$ of apples to consumers, $1.28 \mathrm{~kg}$ need to be produced (Fig. 1). Along the supply chain, those $0.28 \mathrm{~kg}$ of edible and inedible parts of apples are removed for various reasons. Environmental impacts related to these $0.28 \mathrm{~kg}$ of food waste occur during production, processing, retail and distribution, consumer activities (e.g. cooking, storing) as well as food disposal (e.g. composting, waste incineration).

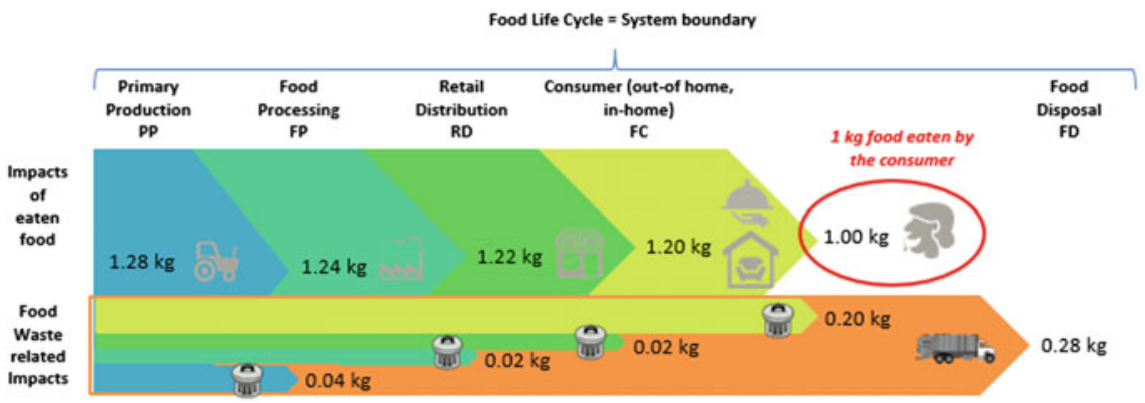

Fig. 1 Stakeholder interactions upstream and downstream of digesters [2] 
The later in the supply chain food is wasted the more environmental impacts are associated with this food waste. Food waste reduction by prevention would therefore avoid those impacts.

Concluding the presentation, she emphasised that taking measures to reduce food waste at the consumer level is key, also for industry. Governments have an important role to play in providing transparency on legal options for food redistribution. By preventing food waste at the consumer level, around 26 Mio tonnes of food can be saved from being wasted (assuming that $57 \%$ of food waste is avoidable). This would result in a reduction potential of 69 Mio tonnes $\mathrm{CO}_{2}$ eq. (corresponding to the level of Finland's total greenhouse gas emissions).

\section{Business Opportunity Through Co-digestion of Dairy Manure in the US}

Methane emissions from food waste landfill and dairy manure anaerobic lagoons are causing significant greenhouse gas emissions (GHG). This case study, presented by Ying Wang, shows how the introduction of a sustainable dairy anaerobic digester system can have co-benefits across the supply chain by turning waste into useful products through industry symbiosis. In this case study, Magic dirt, a trademark for digester-derived nutrient fibre, grew its business from 25 stores in 1 state to 2800 stores in 41 states from 2014 to 2017.

The success of the business model, including complex stakeholder interactions (Fig. 2), depends on multiple factors: (1) Dairy association set up sector GHG reduction targets that incentivises big food companies to "insetting" carbon emissions along their own supply chain; (2) third party investors who construct and operate anaerobic digesters take financial risks away from dairy farmers; (3) secured substrate supply agreements with manure providers and food waste producers, such as commercial, retail and processing sites, and also "off-take agreements" that secure future contracts of selling produced energy to utility companies, nutrient

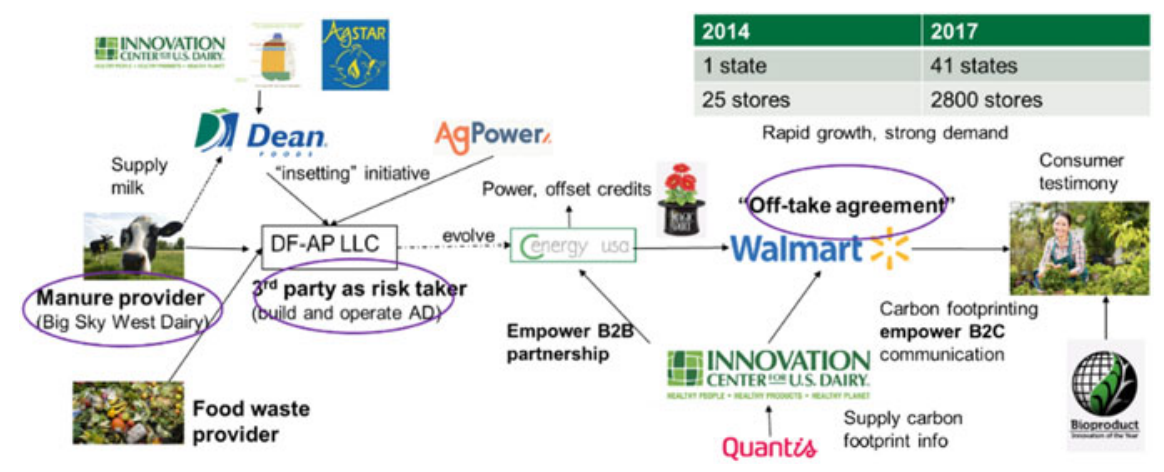

Fig. 2 Stakeholder interactions upstream and downstream of digesters 
fibres to retailers such as Walmart, as well as produced nitrogen and phosphorus to offset commercial fertilisers. Carbon reductions can be also sold as offsetting credits. In this business model, dairy farms and food companies achieved GHG reduction targets and investors profit by converting waste into product, which meet green supplier criteria. Target incentives, collaboration along supply chain, and a business model that balances business risk and opportunities largely contributed to the success. The AgSTAR project of the U.S. EPA [3] analysed the possibility of installing anaerobic digesters with energy generation and nutrient capture in confined animal feeding operations with 500+ cows in the US, suggesting 2647 digesters to be installed nationwide. By implementing the proposed business model to dairy operations and 3rd party digester companies, it could potentially generate 12 Mio MWh of electricity, and also 42 Mio metric tons of $\mathrm{CO}_{2}$ offsetting credits annually, mainly driven by reducing methane emissions from landfilling food waste and manure lagoons, and also avoiding grid electricity production.

\section{The Role of Composting in a Circular Economy}

A decline in soil organic matter (SOM) can be observed in Europe. It is one of the most important indicators for soil quality which hugely affects the agricultural sector and bio-economy. The sustainable management of SOM is an explicit requirement of several international standards and programmes e.g. the EC 16752 Bio-based product sustainability criteria. Food waste and garden waste are common feedstocks for the production of compost. The waste material is collected and biologically treated. The produced compost contains nutrients and humic substances which directly contribute to increase the SOM pool in the soil. Applying compost to agricultural land contributes to improved soil quality and thus bio-economy. Compost use also affects the GHG balance of crops since 58\% of SOM is carbon.

Francesco Razza reported on a case study where compost is applied in a cardoon cropping system in North-East Sardinia. The crop system consists of a rotation of 6 years of cardoon, 1 year of durum wheat and 1 year of field bean, analysed over a time frame of 22 years. One 'compost' scenario, where compost is applied during the 1 st and the 4th year of cardoon is compared to a 'no compost' scenario, where the only organic matter contribution was from above-ground biomass left in the soil after harvest. The trials showed clearly higher levels in SOM increasing steadily over the time frame of 22 years (carbon stock changes are generally calculated over a time frame of 20 years). A GHG balance of the above crop system also showed benefits for the application of compost: $\mathrm{CO}_{2}$ uptakes linked to the increase of SOM in soil have the same order of magnitude as the overall cardoon "Cradle to gate" GHG emissions. Consequently, taking into account SOM dynamics compost scenario shows a reduction of its carbon footprint of $70 \%$ compared to 'no compost' scenario.

Putting this research into the bigger European context shows that only about 1/3 of municipal bio-waste is collected and recycled into high quality compost and digestate while demand for compost clearly outstrips availability. A better 
acknowledgement of the link between bio-waste management, compost quality and the sustainable biomass production required for food security and the wider bio-economy is crucial.

\section{Agri-food Waste Streams Utilisation for Food Substitutes Development}

Food production and consumption systems are changing. This reflects not only on the nutritional need, but also on the popularity of diets such as vegan or flexitarian. Substitution of highly nutritional foods with analogs is gaining momentum. The research presented by Sergiy Smetana focused on the valorisation of agri-food waste streams for food substitutes design. A LCA approach (cradle to plate) was used to assess the environmental impact of different meat substitutes. It showed that depending on the impact or indicator (greenhouse gases, energy, land use or water use) different substitutes show advantages and disadvantages. The comparison was done per weight unit but it needs to be pointed out that different meat substitutes do not have the same nutritional profile. Further his research analysed the potential of waste-to-food application and Technology Readiness Level (TRL) for various biomass sources (e.g. insects, microalgae) in comparison against conventional animal derived products (e.g. chicken, whey concentrate) $[4,5]$.

Overall it was concluded that, traditional food substitution produced with alternative biomass sources is a necessity to design a more sustainable transition to the new food system. For those considerations of TRL, nutritional profile and environmental impact are important to better understand their potential application in the future. State-of-the-art production of meat analogs based on milk, mycoproteins, insects and microalgae biomass are currently not competitive in terms of environmental impact to the benchmark meat (chicken in this case). However, there is a high positive potential of agri-food waste and side streams (molasses, distilled grains, grain brans) application for insect and single cell protein products as food substitutes. The application of agri-food waste streams is complicated but possible for the cultured media production. Application of selected agri-food wastes to produce alternative sources of protein could result in more sustainable source of proteins able to compete with industrial chicken production.

\section{Discussion and Conclusions}

The presentations addressed the topic of food waste management in a circular economy from various angles. Prevention of food waste will be key to meet the UN's Sustainable development goals. Any food waste not prevented should be valorised in a manner such that there is a clear business case, aligning food waste supply with demand for the valorised products, as presented for the US by use of co-digestion. 
The role food waste can play to help mitigate agricultural soil quality losses is maybe not yet widely enough discussed but it is a key to ensure future food supply and input into the bio-economy. Lastly, using food waste as input into food substitute production is a promising technology for the future allowing to reduce pressures on the environment caused by food production. Overall, the presentations and discussions showed the multi-facetted nature of food waste management highlighting that a range of measures by many stakeholders are required to move towards a circular economy society. All of these will require changes in society, in the way we produce and consume food and how we best utilise generated side flows.

Acknowledgements This session was proposed based on work carried out in REFRESH project: 'Resource Efficient Food and Drink for Entire Supply Chain'. REFRESH is funded by the Horizon 2020 Framework Programme of the European Union under Grant Agreement no. 641933 (http:// www.eu-refresh.org).

Moreover, we want to express our honour and gratitude to His Royal Highness Prince Louis of Luxembourg who attended and contributed to this session.

\section{References}

1. European Commission, Closing loop-An EU action plan Circular Economy, Communication from the Commission to the European parliament, the Council, the European economic and social committee and the committee of the regions, C.O.M. 0614, 2015.

2. Scherhaufer S, Moates G, Hartikainen H, Waldron K, Obersteiner G, Environmental impacts of food waste in Europe. Journal of Waste Management. Submitted.

3. U.S. Environmental Protection Agency (USEPA), Market Opportunities for STAR Biogas Recovery Systems at U.S. Livestock Facilities, 2011.

4. Smetana S, Palanisamy M, Mathys A, Heinz V, Sustainability of insect use for feed and food: life cycle assessment perspective, Journal of Cleaner Production, 2016, 137, 741-751.

5. Smetana S, Sandmann M, Rohn S, Pleissner D, Heinz V, Autotrophic and heterotrophic microalgae and cyanobacteria cultivation for food and feed: Life Cycle Assessment. Bioresource Technology, 2017, in press.

Open Access This chapter is licensed under the terms of the Creative Commons Attribution 4.0 International License (http://creativecommons.org/licenses/by/4.0/), which permits use, sharing, adaptation, distribution and reproduction in any medium or format, as long as you give appropriate credit to the original author(s) and the source, provide a link to the Creative Commons license and indicate if changes were made.

The images or other third party material in this chapter are included in the chapter's Creative Commons license, unless indicated otherwise in a credit line to the material. If material is not included in the chapter's Creative Commons license and your intended use is not permitted by statutory regulation or exceeds the permitted use, you will need to obtain permission directly from the copyright holder. 